\title{
CO - MOVEMENTS AND DYNAMIC LINKAGES BETWEEN GOLD PRICE AND CNX NIFTY
}

\author{
KALUNGAN PERUMAL ${ }^{1}$, VELUCHAMY RAMANUJAM ${ }^{2}$ \& KASILINGAM LINGARAJA ${ }^{3}$ \\ ${ }^{1}$ Research Scholar in Management Bharathiar University, Coimbatore, Tamil Nadu, India \\ ${ }^{2}$ Associate Professor, Bharathiar School of Management and Entrepreneur Development (BSMED), Bharathiar University, \\ Coimbatore, Tamil Nadu, India
}

${ }^{3}$ Assistant Professor, Department of Business Administration, Thiagarajar College (Autonomous), Madurai, Tamil Nadu, India

\section{ABSTRACT}

This paper an attempt to examine the movement and linkages (relationship) between Gold price and CNX Nifty index during the period from 2000 to 2018. By testing the normality, stationary, movements and linkages of sample variables through the econometric tools like descriptive statistics, ADF, ARMA and granger causality. It is found that the test results of granger causality are statistically significant at $5 \%$ confidence level. Hence, there is a relationship between gold price and stock market index (CNX Nifty). It is find that the individual investors have often trusted gold as a better investment. Therefore our findings suggest that investors may design appropriate investments with gold and stock market are best investment alternatives during the study period.

KEYWORDS: Co- Movements, Dynamic Linkages, Gold Price, CNX Nifty, Granger Causality, ARMA, Augmented Dickey-Fuller (ADF) and Descriptive Statistics

JEL CLASSIFICATION CODE: C10; E27; G11; O16; R15; Q01

Received: Feb 08, 2020; Accepted: Feb 28, 2020; Published: Nov 17, 2020; Paper Id.: IJMPERDFEB202089

\section{INTRODUCTION}

The purpose of the investment is the way of saving in the future. Investors can save their money with the different way, one of the way is the investment in the shape of the Gold. Different studies have proved that there is positive result in the shape of the gold. Many studies have proved that investment in the gold is the known as the best way of the investment. In the case of financial crisis, it is known as the quite safe. Prior studies showed that there is positive relationship between gold prices and stock exchange, this thing is showing that gold is the safe heaven investment. With the comparison of all metals Gold is known as the own pride. It has the main role from the time of immemorial. At the start, gold was used as the way of exchange and it was also used as the nominal purpose. In simple words it is known as the portfolio investment. Investors have chosen this metal for investment among the different metals. According to different investors Gold is known as the more profitable metal and less risky. Different researchers have proved that there is inverse relationship between gold prices and stock exchange. In the condition of the downturn economy, most of the investors invest into the gold.

The aim of the study is to examine the relationship between gold and stock market. The framework of research focuses on the dynamic interaction to these two variables in the context of Indian economy. The conceptual background and methodology for analysis has been drawn from similar research done by a global perspective. The study begins with an examination of the evolution of gold imports in India. The historical impact 
of gold on the current account deficit and stock market reaction has been examined to build theoretical background. The interaction of gold and stock market is examined by using statistical and econometric tools. The study examines the causal relationship between gold price and CNX Nifty.

\section{LITERATURE REVIEW}

Kwan, Cotsomitis and Kwok (1996) shown that the relationship between gold prices and Canada stock exchange and taken variables namely, stock exchange as the independent variable and gold prices, oil prices as the dependent variables for 10 years i.e., from Feb 2002 to Jan 2012 and utilized the multi regression model. It is found that there is significant relationship between Canada stock exchange and gold prices. They had suggested that investors should invest in the gold rather than stock exchange. Kwon and Shin (1999) investigated that the relationship between gold prices and Andorra stock exchange. The secondary data period collected from 1998 to 2012 and variables namely, stock exchange as the independent variable and gold prices as the dependent variables, used the statistical tools like, cointegration and causality model. It is to be noted that there is significant relationship between Andorra stock exchange and gold prices. It is suggested that investors should invest in the gold rather than stock exchange. Perry Sadorsky (1999), viewed that the relationship between gold prices and Egypt stock exchange for eight years, from Feb 2007 to Jan 2015 and applied the ARCH model. The variables namely, stock exchange as the independent variable and gold prices as the dependent variables were taken. It is found that there is significant relationship between Egypt stock exchange and gold prices. It is to be suggested that investors should invest in the gold rather than stock exchange. Graham Smith, 2001 Observed that the relationship between gold prices and Malaysia stock exchange for the data collected from 2003 to 2013 and utilized the Johnson approach model and selected the sample variables namely, stock exchange as the independent variable and gold prices, oil prices as the dependent variables. It is found that there is significant relationship between Malaysia stock exchange and gold prices. It is to be suggested that investors should invest in the gold rather than stock exchange. Maghayereh, Aktham (2003) Analyzed that the relationship between gold prices and Korea stock exchange during the period from Feb 1999 to Jan 2011 and applied statistical tools like, the VECM model. They had taken variables namely, stock exchange as the independent variable and gold prices, oil prices as the dependent variables, they had shown the results that there is significant relationship between Andorra stock exchange and gold prices. It is to be suggested that investors should invest in the gold rather than stock exchange. Ramazan Safi and Ugur Soytas (2006) Analyzed that the relationship between gold prices and Bangladesh stock exchange. For this purpose they were collected the data from 2001 to 2014 and utilized the VECM model. They had taken variables namely, stock exchange as the independent variable and gold prices, oil prices as the dependent variables. It is found that there is significant relationship between Bangladesh stock exchange and gold prices. They had suggested that investors should invest in the gold rather than stock exchange. Claire, et.al., 2009 shown that the relationship between gold prices and France stock exchange and collected the data for the period from 2001 to 2011 and applied the simultaneous equation model and selected variables namely, stock exchange as the independent variable and gold prices, oil prices as the dependent variables. It is to be noted that there is significant relationship between France stock exchange and gold prices. They had suggested that investors should invest in the gold rather than stock exchange. Mu-Lan, Ching-Ping and Tzu-Ying (2010), Examined that the relationship between gold prices and Hong Kong Stock exchange index. For this purpose they were collected the data from 2003 to 2013 and utilized the GARCH model. They had taken variables namely, stock exchange as the independent variable and gold prices, oil prices as the dependent variables, they had shown the results that there is significant relationship between Hong Kong. Stock exchange and gold prices. They had suggested that investors should invest in the gold rather than stock exchange. 
Hina et al. (2011) conducted the research regarding the gold and KSE100 index relationship. Johansen's co-integration test was applied the results revealed that there was long run relationship between gold and KSE100 Index. Ray (2012) tested the Granger causality test and multiple regression model to identify the impact of different macroeconomic variables on stock market. The empirical results showed that gold price and oil price have significant negative effect on stock returns in India. Sulaiman et al. (2012) judged the positive relationship between KSE100 Index and gold prices using Arbitrage pricing Theory (APT). Hamed Sadri and Ehsan TayebiSani (2012) applied that the relationship between gold prices and Afghanistan stock exchange. For this purpose they were collected the data from 2007 to 2015 and utilized the ECM model. They had taken variables namely, stock exchange as the independent variable and gold prices, oil prices as the dependent variables and found that there is significant relationship between Afghanistan stock exchange and gold prices. Lingaraja et al. (2014) examined the linkages and movements between emerging markets and developed markets in Asia. It was found that the five emerging markets, namely, China, Indonesia, Korea, Malaysia and Thailand, recorded higher risk than India, Taiwan and Philippines. Ramanujam, $V$ and $L$ Leela (2014), examined that the impact of changes in selected macro variables upon the movement of stock Market Index, i.e., CNX NIFTY for the period from January 2004 to December 2013. A Multiple Regression Model has been used to estimate the relationship. Based on regression coefficient, it was found that exchange rate and gross domestic product have influence the NSE Stock Index. Işıl Akgül, et al., (2015) investigated the nonlinear linkage between gold prices and stock market index for the period from 1986:04 to 2013:11. It is employed Bayesian approach to econometrics provides a general method for combining modeller's beliefs with the evidence contained in the data. It is used gold prices (USD/oz.) and S\&P 500 Stock Price Index as an endogenous, the crude oil prices (Brent-\$/barrel) as an exogenous variable in the analysis. It is prior distribution are employed to estimate the models. Cuong Nguyen, et al., (2016), investigated the role of gold as a safe haven in international stock markets applied various copula techniques to capture complex dependencies between stock markets and gold prices. It employed parametric and nonparametric copulas to over 11 years of daily data (1999-2010) from seven countries' to understand the nexus between international stock markets and gold prices. It is found that gold may be a safe haven asset during market crash for the case of Malaysia, Singapore, Thailand, the UK and the US markets but not for the Indonesian, Japanese and the Philippines markets. Dennis Bams, et al., 2017, investigated the uncertainty in the stock oil and gold markets with the variance risk premia, extracted from futures and option contracts. It is observed that an independent increase in the stock, oil or gold markets uncertainty coincides with negative returns in different industries. It is found that only the stock market uncertainty is a systematic priced factor in the entire cross section of stocks' expected returns. It is noted that Gold price uncertainty is an asset-specific factor that is neither priced across nor within industries. Shubhasis, Dey and Aravind Sampath (2018), analyzed dynamic linkages between gold and equity price by applied multivariate GARCH models. A $\$ 1$ long position in the NIFTY Financial Services index or in the NIFTY Information Technology index can be hedged for 12 cents and 5 cents, respectively, with a corresponding short position in spot gold. It is found that the spot gold expressed in rupees is a stronger equity hedge than spot gold expressed in dollars. It is interesting to note that Gold also acts as a safe haven asset during the Global Financial Crisis period. It is suggested that crisis or not a prudent investor should allocate around 30\% of her investable assets in gold within a gold/stock portfolio. Muhammad Akbar, et al., (2019), examined dynamic linkages among gold price, stock prices, exchange rate and interest rate nexus using monthly data of Pakistan economy ranging for the period from 2001-1 to 2014-12. Hence, the study is also used to compare performance of classical VAR model and Bayesian VAR model under four types of priors. It is found that the inverse bilateral relationships between stock prices and gold price as well as between rupee value and gold price are determined where as positive bilateral relationship between stock prices and rupee value is explored. It is to be noted that gold is not only 
considered as safe haven but it is also considered as an alternative investment during adverse fluctuations in stock and foreign exchange markets of Pakistan. Nafeesa Yunus (2020), examined the time-varying linkages among gold, stocks (large-cap, mid-cap and small-cap), bonds (corporate, T-Bond and T-Bill), and real estate, in order to evaluate the hedging and safe haven properties of gold under differing market conditions. The data set in the samples were Long-run results indicate that gold is integrated with each asset class during the pre-crisis (1985-2007) period indicating that it does not serve as a hedge during tranquil regimes and Short-run analysis of the crisis only (2007-2009). It is noted that the response of gold to shocks from key economic variables does not contradict the reaction of other variables to the same shocks indicating that gold does not serve as a strong safe haven during periods marked by high volatility. Lingaraja, et al. (2020), examined the long-run volatility and causality effects of Sri Lankan (LKR) currency and nine currency of emerging countries in Asia against USD over 17 years i.e., from 01st January, 2002 to 31st December, 2018 by using the Descriptive Statistics (Summary), GARCH $(1,1)$ Model, Correlation and Granger Causality Test. It is found that the significant currencies movements and the Granger causality test indicates the strong evidence that the causation runs between Sri Lankan currency (LKR / USD) to nine Asian emerging countries currency price behavior against USD. Osamah M.Alkhazali and Taisier A.Zoub (2020), examined the role of gold in diversification of eight Dow Jones Islamic stock index portfolios from 1996 to 2017 and applied the statistical tools like stochastic dominance (SD) approach, it tests the null hypothesis that gold-Islamic stock portfolio return does not dominate (outperform) non-gold Islamic stock portfolio return. It is noted that a gold-Islamic stock portfolio stochastically dominates one without gold at the FSD, SSD, and TSD orders in all Islamic stock indices. Moreover, the level of SD order increases when we add more gold to the portfolio. It is found that the SD order is manifest during the financial crisis (2007-2009) at all percentage holdings of gold. It is to be suggested that investors may design appropriate investments with gold to diversify their Islamic stock portfolios.

\section{RESEARCH METHODS}

\section{Research Gap}

Based on the former literature it can be noticed that there is a gap of knowledge in this topic as this relationship was not studied thoroughly as it either lacks conducting sufficient tests in the same paper or being included as a secondary relationship along with other variables. It was noticed also that European zone lacks such studies that consider the relationship between gold and stock market as only one study was found, this study also included other variables, did not conduct enough tests and didn't focus on a certain country. Therefore, the researchers opted to fill this gap of knowledge by choosing and conducting such new emerging kind of study that examines and focuses on the relationship of gold and its effect on stock market index (Nifty) will contribute massively to the gap of knowledge.

\section{Research Questions}

The corporate earnings and stock market performance depends on economic stability. India is one of the largest import and consumer of gold. The gold import does not make any significant contribution to industrial production. A large portion of gold import is used for making jewellery. However, increase in gold import adversely affect the current account deficit. The following are the research question framed for the study

- How gold price is linked to macro-economic factors and stock market performance?

- Does gold price granger cause stock market returns?

- Is there volatility spillover effect among the variables? 


\section{Research Design}

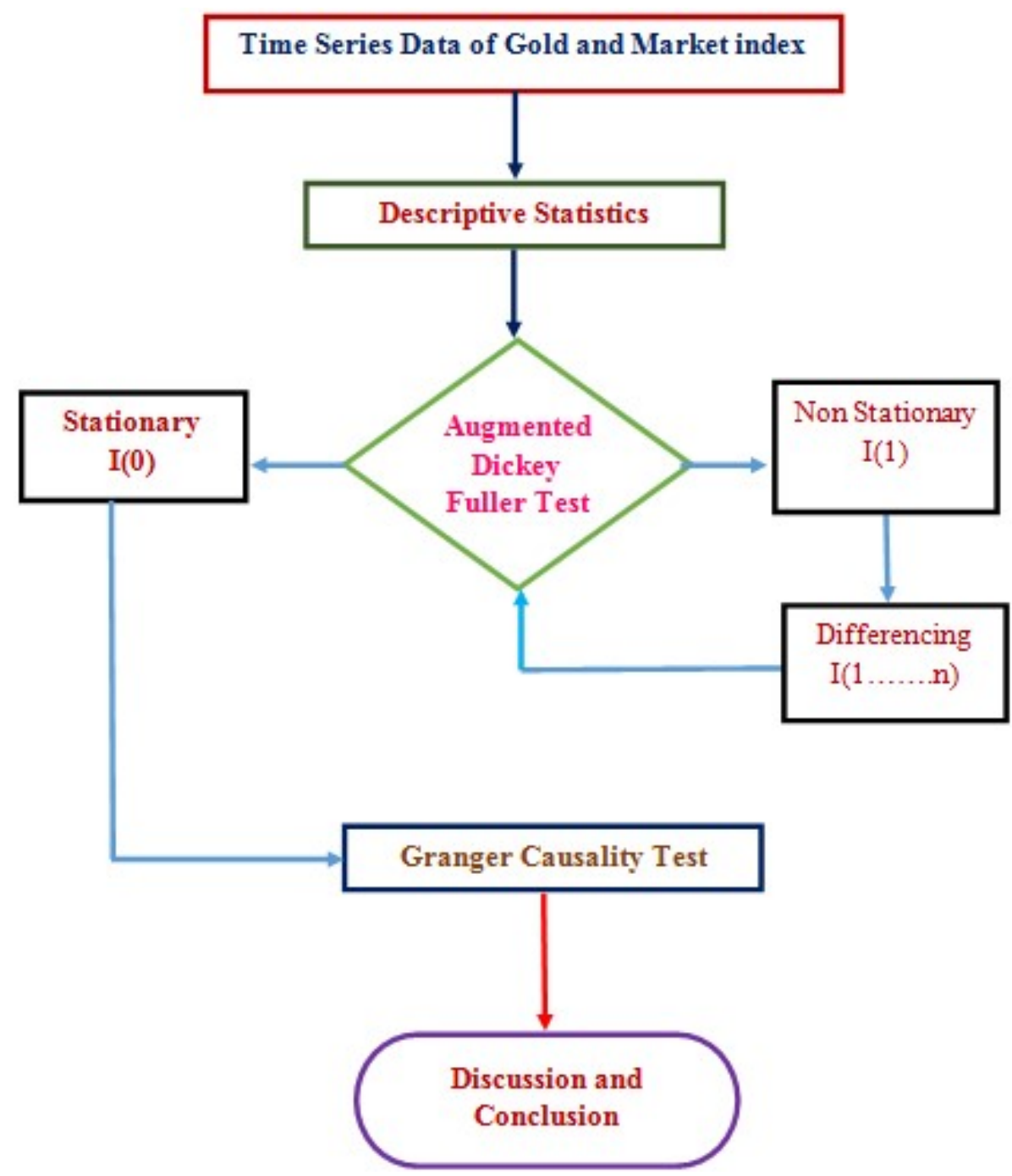

Figure 1

\section{Statement of the Problem}

India is the largest importer of gold, which mainly caters to the demand of the jeweler industry. In volume terms, the country imports 700-800 tonnes of gold annually. The country's gold imports, which has a bearing on the current account deficit (CAD), increased by 22.31 per cent to USD 33.65 billion in 2017-18, according to Commerce Ministry data. Imports of the yellow metal stood at USD 27.51 billion in 2016-17 financial year. In 2015-16, the imports aggregated at USD 31.7 billion. CAD, which is the difference between the inflow and outflow of foreign exchange, jumped to USD 48.7 billion, or 1.9 per cent of GDP, in 2017-18 fiscal. A higher trade deficit due to increase in Gold import would widen the current account deficit. The twin deficit would put the rupee under pressure. A huge current account gap could make the rupee depreciate, adversely affecting the companies that rely more on imports. Though rupee depreciation is beneficial to export oriented firms, India is apparently an import oriented economy. Therefore, there is a not to examine the gold price changes on the stock market. 


\section{Objectives of the Study}

The objectives of the study are as follows

- To analyze the effect of change in gold price on the macro economic factors

- $\quad$ To examine the causal relationship between gold and stock market returns

- To examine whether there is any price discovery mechanism that exist between Gold and stock return

- To analyses the spillover effect among the two variables

\section{Hypotheses of the Study}

The following are the hypotheses of the study

- $\mathrm{H}_{\mathrm{o}}$ : The series of gold price are not stationary or it has got unit root

- $\mathrm{H}_{0}$ : Gold price does not Granger cause stock market returns

- $\mathrm{H}_{0}$ : Market returns does not Granger cause gold price

- $\mathrm{H}_{0}$ : There is no spillover effect between gold and market returns

\section{Data Collection}

The stock market return is India is measured by taking the monthly returns of NIFTY index. Similarly, the historical gold price has also been adjusted for inflation using consumer price index. Monthly data of gold and market returns are used for data analysis.

\section{Period of Study}

For achieving the above objectives, the research study covered a period of 18 years i.e., between 2000-01 and 2017-18 both Gold and CNX Nifty.

\section{Tools Employed for Analysis}

The study has adopted statistical and econometric tools. The following are the tools adopted for the study.

- Descriptive statistics to analyse the characteristics of time series data of gold and Nifty index

- Jarque Bera test, to test the normality, Durbin Watson test to test autocorrelation, Augmented Dickey Fuller test to test for stationarity.

- $\quad$ ARMA to test the accuracy of forecasting.

- Granger Causality test to test the relationship between the price movement of gold and market returns.

\section{LIMITATIONS OF THE STUDY}

The analysis and interpretations are drawn based on the historical price of gold and Nifty market returns. The following are the limitation of the study. 
- The study is based on the historical data of gold. The Gold is highly regulated by the Government. Any major regulatory measure may affect the market performance positively or negatively.

- The stock markets in India are highly regulated. Any change in regulation may change the underlying fundamental and may have an impact on the assumptions of the study.

\section{RESULTS OF GOLD PRICE AND STOCK MARKET ANALYSIS}

As said already, the main aim of this study was to analyse the linkages of Gold price and stock market index (CNX nifty). The analysis is presented as follows.

\section{An Analysis of Gold Demand and Price during the Study Period}

India is one of the largest markets for gold, and growing affluence is driving growth in demand. Gold has a central role in the country's culture, considered a store of value, a symbol of wealth and status and a fundamental part of many rituals. Among the country's rural population, a deep affinity for gold goes hand in hand with practical considerations of the portability and security of jewellery as an investment.

Gold is considered to be auspicious, particularly in Hindu and Jain cultures. The ancient law-giver Manu decreed that gold ornaments should be worn for important ceremonies and occasions. Aside from Diwali, one of the most important dates in the Indian calendar, regional festivals across the country are celebrated with gold: in the south, Akshaya Tritiya, Pongal, Onam and Ugadi; in the east, Durga Puja; in the west, Gudi Pavda; in the north, Baisakhi and Karva Chauth.

Gold is central to more personal life events too. Gifting gold is a deeply ingrained part of marriage rituals in Indian society weddings generate approximately 50 percent of annual gold demand.

\section{Factors Influencing Gold Price in India}

India is one of the largest markets for gold, and growing affluence is driving growth in demand. Gold has a central role in the country's culture, considered a store of value, a symbol of wealth and status and a fundamental part of many rituals. Among the country's rural population, a deep affinity for gold goes hand in hand with practical considerations of the portability and security of jewellery as an investment.

Gold is considered to be auspicious, particularly in Hindu and Jain cultures. The ancient law-giver Manu decreed that gold ornaments should be worn for important ceremonies and occasions. Aside from Diwali, one of the most important dates in the Indian calendar, regional festivals across the country are celebrated with gold: in the south, Akshaya Tritiya, Pongal, Onam and Ugadi; in the east, Durga Puja; in the west, Gudi Pavda; in the north, Baisakhi and Karva Chauth.

Gold is central to more personal life events too. Gifting gold is a deeply ingrained part of marriage rituals in Indian society—weddings generate approximately 50 percent of annual gold demand.

Indians buy gold mainly for the purpose of making jewelry and as an investment. A lot of Indians consider gold to be one of the safest investments, as it can be liquidated very easily in times of need.

Gold is the most popular asset in India. It is an integral part of all celebrations and festivities in India. India is the largest importer of the yellow metal, and rightly so. India is the consumer of about $30 \%$ of the world's gold. One can spot a lot of gold ornaments at a single wedding in India. Indians buy gold mainly for the purpose of making jewelry and as an 
investment. A lot of Indians consider gold to be one of the safest investments, as it can be liquidated easily in times of need.

Lately, the prices of gold have been in a downward spiral since the past couple of months. As of mid July, prices for 22 karat gold are at around 27,000 rupees per 10 grams. The reason for this particular downward spiral in the prices is very complicated. However, as a rough guide, here are a few general factors that impact the price of gold in India (World gold council).

\section{- The Jewellery Markets}

The jewelry market plays an important role in affecting gold prices. In India, a vast amount of gold purchased is utilized in the form of gold ornaments and jewelry. The jewelry market in India is huge and is fuelled by various Indian festivals and sentiments. A lot of Indians choose festival seasons for buying gold, keeping in view of an auspicious occasion. Hence, festival seasons see increased prices for the precious metal, due to very high demand. The demand-supply mismatch inflates the price of the metal for a short while.

\section{- Inflation}

Gold is considered to be a very safe investment at all times. This becomes particularly true during times of inflation. Effectively, inflation reduces the purchasing power of money. When one is careful in spending money, one has to be even more careful while investing it. The correct investment during times of inflation would be in something that is stable, and has been so for a long time now. Gold is the answer to this problem. Gold makes for an excellent investment choice during inflation, as it is largely stable. It is among the world's most respected mediums of exchange. The demand for gold increases during times of inflation, thus affecting its price.

\section{- Changes in Global Prices}

Given that India imports a majority of its gold requirements, it is only natural that the price of gold in India will be affected by changes in global prices. Global prices for the metal may change due to a number of factors, such as change in global supply, change in demand, etc. Since India imports gold, its price is linked to the international gold prices. Changes in global prices of the precious metal are also reflected in domestic prices.

\section{- Central Bank Gold Reserves}

Central banks hold massive reserves of gold, in addition to currencies. When the central bank of a country starts to acquire and hold gold, its price generally shoots up. This rise in price is due to increased supply of money and decreased supply of gold.

\section{- Fluctuating Rates of Interest}

Rates of interest on financial instruments and bank deposits also play a major role in determining the price of gold. Increased interest rates imply that people will sell their gold to put their money to better use. A lower rate of interest translates to more cash in the hands of the individual, and more capacity to buy gold.

\section{- The Bottom Line}

Prices of gold go up and down all the time. As mentioned above there are a lot of factors at play that decide the price of the yellow metal. 


\section{Gold Sectoral Demand (Source: World Gold Council)}

\section{- Jewellery Demand}

Gold jewellery represents the largest source of annual demand for gold per sector. This has declined over recent decades, but it still accounts for around $50 \%$ of total demand.

India and China are by far the largest markets, in volume terms, together accounting for over $50 \%$ of current global gold demand. The Asian and Middle Eastern markets are dominated by demand for purer, high-caratage gold.

\section{- Investment Demand}

Gold has unique properties as an asset class. Modest allocations to gold can be proven to protect and enhance the performance of an investment portfolio. Even so, globally, gold still only makes up less than one per cent of investment portfolios.

However, this is changing and investors of all sorts are coming to accept gold as a reliable, tangible long-term store of value that has moved independently of other assets. The annual volume of gold bought by investors has increased by at least $235 \%$ over the last three decades.

Our analysis shows that gold can be used in portfolios to protect purchasing power, reduce volatility and minimise losses during periods of market shock.

\section{- Central Bank Demand}

The past decade has seen a fundamental shift in central banks' behaviour with respect to gold, prompted by reappraisal of its role and relevance after the 2008 financial crisis. Emerging market central banks have increased their official gold purchasing, while European banks have ceased selling, and the sector now represents a significant source of annual demand for gold.

Central Banks sold 7,853 tonnes of gold between 1987 and 2009; between 2010 and 2016 they bought 3,297 tonnes.

\section{- Technology}

Gold has long been central to innovations in electronics. Today the unique properties of gold and the advent of 'nanotechnology' are driving new uses in medicine, engineering and environmental management.

Gold can be used to build highly-targeted methods for delivering drugs into the human body, to create conducting plastics and specialised pigments, or advanced catalysts that can purify water or air. It has also been used in dentistry for centuries. Although most technological applications use low volumes of gold, their impacts are very diverse and widereaching. 


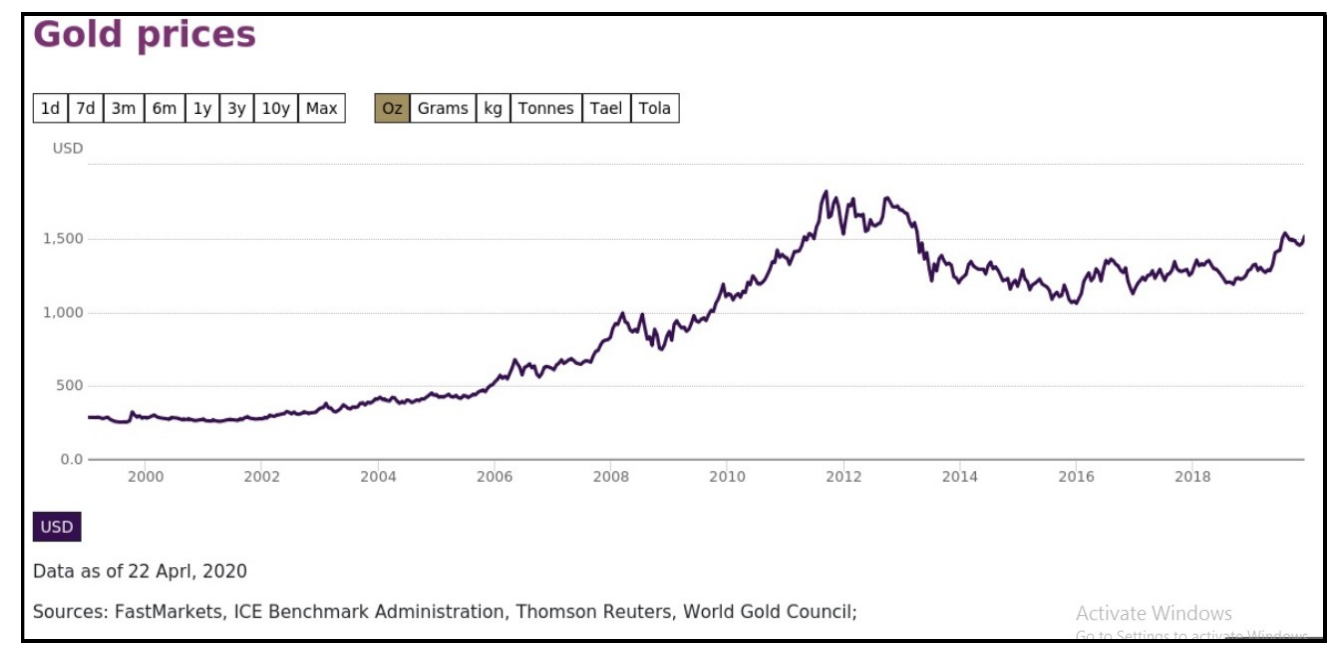

Figure 2: Gold Price Trend from 2000 to 2018.

The above Figure - 2 shows the trend of Gold price of Gold for the period between 2000 and 2018. Linear trend is observed in the price movement since 2000. The rate of price increase between 2000 and 2012 is higher than the price change from 2013 to 2019. The price chart indicates seasonal and cyclical movements. The seasonal variations reflect the peak and non peak seasons of Gold. Studying the gold rate trend in India could offer an insight into future fluctuations and investment plans can be made accordingly. The gold rate depends on a number of factors like the stability of the central bank, the supply and demand of gold in the market, quantitative easing, government reserves, the health of the jewellery industry and overall yearly production to name a few.

Gold prices in 2018 saw some significant fluctuations due to ongoing geopolitical tensions in the United States, which impacted the U.S. dollar rate and influenced global bullion demand. Local demand for the yellow metal was influenced by the fluctuating rupee rate, which continued to play second fiddle to the dollar. The ongoing Brexit crisis caused fluctuations across the Eurozone, which led to a surge in bullion demand towards the end of the year. The U.S government shutdown also served to pressure the U.S. dollar, though gold rates did not see much impact at the time.

The above figure- 3 shows the box plot of gold price for the period between 2000 and 2018. The minimum price for the period of observation is $\$ 371.70$ per ounce and the maximum price is $\$ 2033.05$. The mean and median values are $1,030.90$ and 1,354.53 respectively. The first quartile price of the observation period is $\$ 548.94$ and the third quartile value is $\$ 1,354.53$ per ounce. The interquartile range is 982.83 .

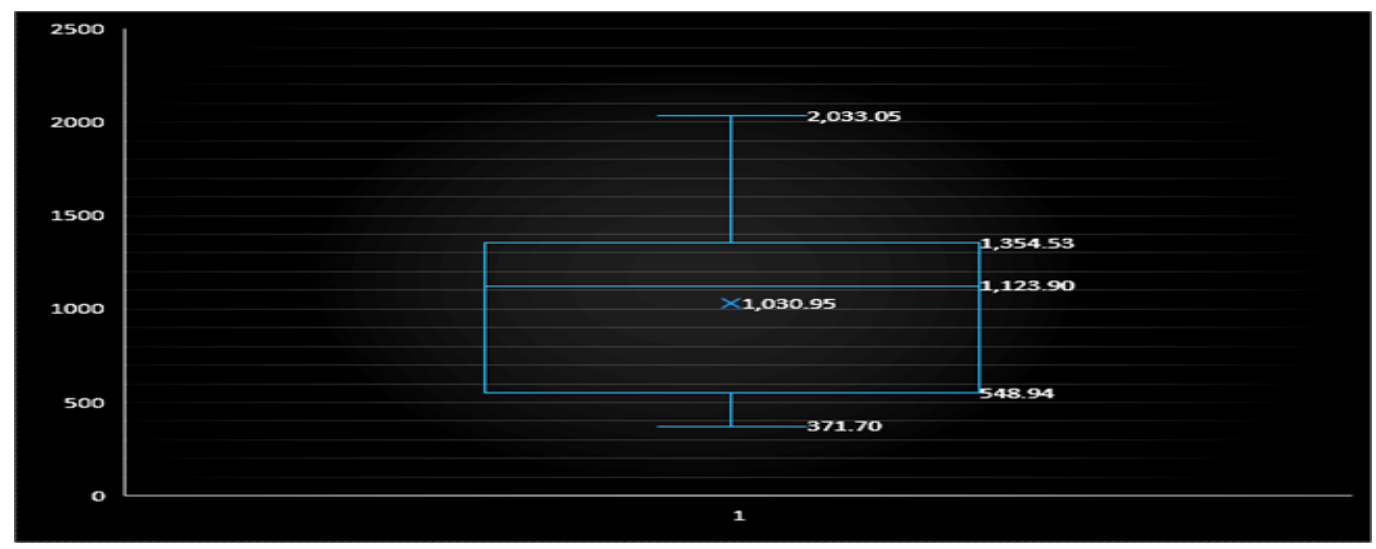

Figure 3: Box Plot of Gold Price during the Study Period. 
The 'Gold: Second Half Increase' is the seasonal rise in gold, starting on May 5 and ending on January 21 of the following year. The increase was observed in 20 of 30 years, resulting in an average profit of $+19.2 \%$. But there were also 10 years, where the price of gold fell during this period of the year. The average loss then was $-12.3 \%$. The overall rise during all 30 years was $+7.6 \%$ p.a.

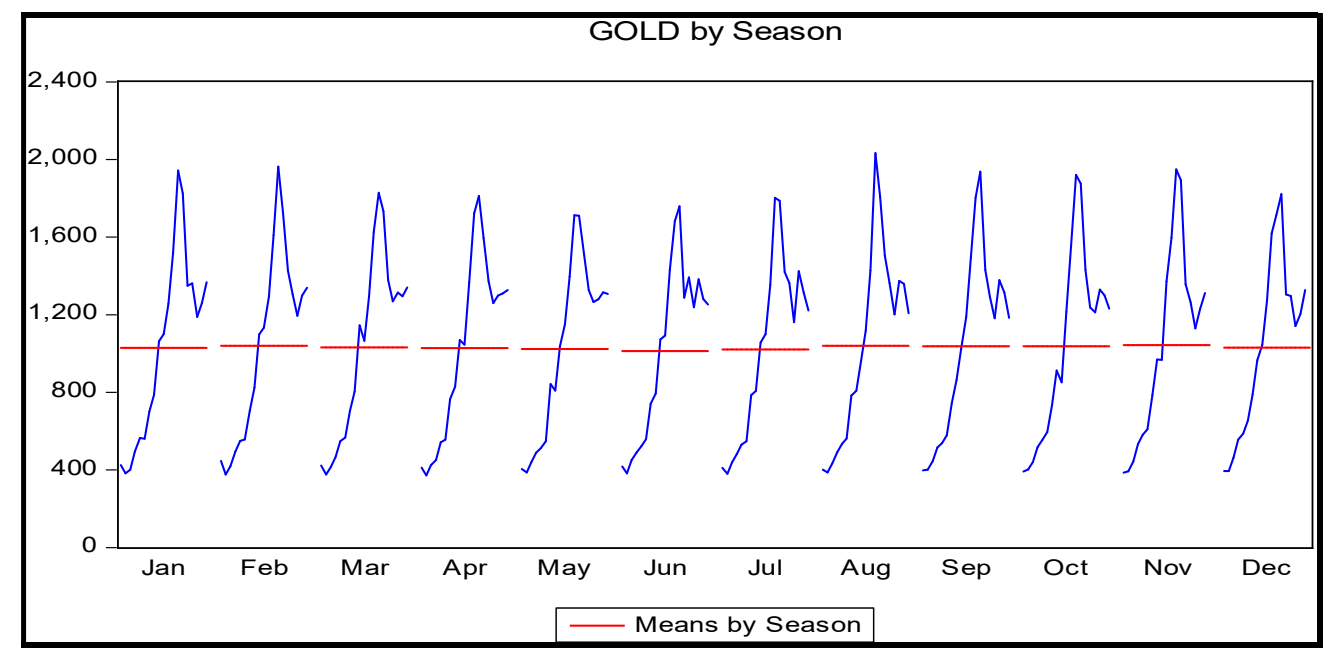

Figure 4: Seasonal Variation in Gold Price during the Study Period.

The 'Gold: Second Half Increase' lasts 259 calendar days. It took place in $66 \%$ of all years. Thus the statistical stability of this seasonal pattern is acceptable. It is necessary to take steps to minimize losses.

With an annual demand equivalent to about 25 percent of the total physical demand worldwide, India is one of the largest consumers of gold. Traditionally, there is a surge in jewellery demand during the festive and wedding seasons, leading to a rally in gold prices. While the demand for gold has a role to play in its price, there are several other factors that have a bearing on it as well.

According to a report by the World Gold Council, annual data from 2000 to 2018, revealed two significant factors affecting gold consumer demand (jewellery, and bar and coin combined) over the long-term. "All else being equal, gold demand is driven firstly by, income i.e. gold demand is seen to rise with income levels. For a 1 percent increase in income per capita gold demand rises by 1 percent and secondly, gold price level i.e. higher prices deter gold purchases. For a 1 percent increase in prices, gold demand falls by 0.5 percent."

\section{Descriptive Statistics and Significance Test of Gold Price}

Table 1: Descriptive Statistics and Test of Significance of Time Series Data of Spot Price of Gold for the Period from 2000 to 2018

\begin{tabular}{|c|c|c|}
\hline \multicolumn{3}{|l|}{ Descriptive Statistics } \\
\hline Average spot price & & 1030.953 \\
\hline Standard Deviation & & 463.0951 \\
\hline Skewness & & 0.111758 \\
\hline Excess Kurtosis & & 1.884079 \\
\hline Median & & 1123.900 \\
\hline \multicolumn{3}{|l|}{ Significance Test } \\
\hline Test & p-value & Significance@5\% \\
\hline White -noise & $0.00 \%$ & Significant \\
\hline ARCH (Auto Regressive Conditional Heteroskedasticity) Effect & $0.00 \%$ & Significant \\
\hline
\end{tabular}


The Table - 1 shows the descriptive analysis of the time series data of spot price of Gold for the period between 2000 and 2018. The analysis indicates the mean is significantly different from zero. The Skewness value of 0.11 shows the distribution of variables is positively skewed. The kurtosis (1.88) indicates the density distribution has narrow-tails. The white noise and $\mathrm{ARCH}$ test are significant at $5 \%$ confidence level. It indicates the mean of the series of Gold price is not constant during the period of observation.

\section{Augmented Dickey Fuller Test for the Series of Gold Price}

The unit root test examines whether the time series variables are stationary using an autoregressive model. Augmented Dickey Fuller Test (ADF) test is applied to test whether the time series data of gold price is Stationary. The monthly average gold price for the period between 2000-01 and 2017-18 had been considered for unit root test.

\section{The following are the hypothesis framed to test unit root}

Null hypothesis Ho: The series of gold price are not stationary or it has got unit root

Alternate hypothesis $\mathrm{H}_{1}$ : The series of gold price is stationary.

Table 2: Critical values for Dickey Fuller $t$ distribution of Gold Price during the Study Period

\begin{tabular}{|c|c|c|c|c|}
\hline \multicolumn{5}{|c|}{ Critical Values for Dickey Fuller t-Distribution } \\
\hline & \multicolumn{2}{|c|}{ Without Trend } & \multicolumn{2}{c|}{ With Trend } \\
\hline Sample Size & $\mathbf{1 \%}$ & $\mathbf{5 \%}$ & $\mathbf{1 \%}$ & $\mathbf{5} \%$ \\
\hline $\mathrm{T}=25$ & -3.75 & -3.00 & -4.38 & -3.60 \\
\hline $\mathrm{T}=50$ & -3.58 & -2.93 & -4.15 & -3.50 \\
\hline $\mathrm{T}=100$ & -3.51 & -2.89 & -4.04 & -3.45 \\
\hline $\mathrm{T}=250$ & -3.46 & -2.88 & -3.99 & -3.43 \\
\hline $\mathrm{T}=500$ & -3.44 & -2.87 & -3.98 & -3.42 \\
\hline $\mathrm{T}=\alpha$ & -3.43 & -2.86 & -3.96 & -3.41 \\
\hline
\end{tabular}

The hypothesis is tested for the following three level of equation i.e Intercept only, Trend and intercept and no intercept and the results are shown in tables $3,4 \& 5$.

Table 3: ADF Test of Gold Price for the Period between 2000-01 and 2017-18 (Only Intercept)

\begin{tabular}{|l|c|c|c|c|}
\hline \multicolumn{1}{|c|}{ Variable } & Coefficient & \multicolumn{1}{|c|}{ Standard Error } & t-Statistic & Probability \\
\hline Gold & -0.010750 & 0.008546 & -1.257930 & 0.2097 \\
\hline C & 15.22215 & 9.662907 & 1.575318 & 0.1166 \\
\hline R- squared & 0.041061 & Mean dependent variable & 3.503839 \\
\hline Adjusted R-squared & 0.032383 & S.D dependent variable & 60.04977 \\
\hline Standard Error of regression & 59.06947 & Akaike Information criterion & 11.00861 \\
\hline Sum squared residual & 771113.6 & Schwarz criterion & 11.05430 \\
\hline Log Likelihood & -1229.964 & Hannan-Quinn criterion & 11.02705 \\
\hline F- statistic & 4.731550 & Durbin - Watson statistic & 2.027462 \\
\hline Probability (F- statistic) & 0.009725 & \multicolumn{3}{|}{} \\
\hline
\end{tabular}

Note: Exogenous: Constant, Lag length: 0 (Automatic - based on Schwarz criterion, Max lag =11)

The Table - 3 indicates the results of ADF test for the series of gold price between 2000-01 and 2017-18. The results of the test are analysed through $\mathrm{p}$ values and $\mathrm{t}$ statistic. The observed $\mathrm{p}$ value is 0.2097 , which is more than $5 \%$. The test results are not statistically significant at $5 \%$ confidence level. Therefore the null hypothesis of non stationarity is accepted. It indicates the time series data of gold price for the period of observation is non stationary. 
Table 4: ADF Test of Gold Price for the Period between 2000-01 and 2017-18 (Trend and Intercept)

\begin{tabular}{|l|c|l|c|c|}
\hline \multicolumn{1}{|c|}{ Variable } & Coefficient & \multicolumn{1}{c|}{ Standard Error } & t-statistic & Probability \\
\hline C & $\mathbf{1 . 8 4 2 7 9 4}$ & $\mathbf{2 . 8 8 9 9 7 4}$ & $\mathbf{0 . 6 3 7 6 5 1}$ & $\mathbf{0 . 5 2 5 3}$ \\
\hline Trend & $\mathbf{0 . 2 0 8 6 9 9}$ & $\mathbf{0 . 1 1 7 0 6 5}$ & $\mathbf{1 . 7 8 2 7 5 7}$ & $\mathbf{0 . 0 7 7 9}$ \\
\hline R- squared & 0.033393 & Mean dependent variable & 3.133158 \\
\hline Adjusted R-squared & 0.012379 & S.D dependent variable & 13.90808 \\
\hline Standard Error of regression & 13.82173 & Akaike Information criterion & 8.121430 \\
\hline Sum squared residual & 17575.69 & Schwarz criterion & 8.202079 \\
\hline Log Likelihood & -382.7679 & Hannan-Quinn criterion & 8.154018 \\
\hline F- statistic & 1.589128 & Durbin - Watson statistic & 1.850856 \\
\hline Probability (F- statistic) & 0.209654 & & \\
\hline
\end{tabular}

Note: Exogenous: Constant, Linear Trend. Lag length: 0 (Automatic - based on Schwarz criterion, Max lag =11)

The Table- 4 indicates the results of ADF test (trend and intercept) for the series of gold price between 2000-01 and 2017-18. The results of the test are analysed through $p$ values and t statistic. The observed $p$ value is 0.7871 , which is more than $5 \%$. As per the guidelines the null hypothesis is rejected only if the observed p value is less than $5 \%$. Since the observed $\mathrm{p}$ value $(0.7871)$ is more than $5 \%$, the null hypothesis is accepted. It indicates the time series data of gold price for the period of observation is non stationary.

The observed $\mathrm{t}$ statistic value is -1.59 . As per the guidelines the null hypothesis is accepted if the observed $\mathrm{t}$ statistic is less than the critical value. Since the observed t statistic value (-1.59) is less than the critical value (-3.45), the null hypothesis is accepted. Hence the analysis of ADF test indicates the time series data of gold price for the period of observation is non stationary.

Table 5: ADF Test of Gold Price for the Period between 2000-01 and 2017-18 (No Trend and Intercept)

\begin{tabular}{|l|c|l|c|c|}
\hline \multicolumn{1}{|c|}{ Variable } & Coefficient & \multicolumn{1}{|c|}{ Standard Error } & t-statistic & Probability \\
\hline C & 15.29297 & 9.694239 & 1.577532 & 0.1161 \\
\hline Trend & 0.017130 & 0.106313 & 0.161131 & 0.8721 \\
\hline R- squared & 0.041174 & Mean dependent variable & 3.503839 \\
\hline Adjusted R-squared & 0.028100 & S.D dependent variable & 60.04977 \\
\hline Standard Error of regression & 59.20007 & Akaike Information criterion & 11.01742 \\
\hline Sum squared residual & 771022.6 & Schwarz criterion & 11.07834 \\
\hline Log Likelihood & -1229.951 & Hannan-Quinn criterion & 11.04201 \\
\hline F- statistic & 3.149119 & Durbin - Watson statistic & 2.026787 \\
\hline Probability (F- statistic) & 0.025896 & & \\
\hline
\end{tabular}

Note: Exogenous: None, Lag length: 0 (Automatic - based on Schwarz criterion, Max lag =11

The Table- 5 indicates the results of ADF test (no trend and intercept) for the series of gold price between 200001 and 2017-18. Since the co efficient obtained through ADF test is not negative, it is inferred that the results are inconclusive.

\section{Conversion of Non Stationary Variables to Stationary Variables}

The application of ADF test for the raw data of the gold price indicates the time series data is non stationary. Therefore, forecasting of prevailing future price of Gold cannot be done appropriately. In order to make the observed prices compatible to use in the forecasting model, it has to be converted into stationary. The conversion of non-stationary to stationary can be done by taking the first difference of the variable.

The first difference of the monthly gold price for the period between 2000-01 and 2017-18 had been taken to convert the variables into stationary from non-stationary. ADF test is applied to verify whether the first difference variables 
are stationary. The hypothesis is tested for the following three level of equation i.e. only Intercept, Trend and Intercept and No intercept. The results are shown in Tables - 6,7 and 8 .

Table 6: ADF Test for First difference of Gold Price for the Period between 2000-01 and 2017-18 (Only Intercept)

\begin{tabular}{|l|c|l|c|c|}
\hline \multicolumn{1}{|c|}{ Variable } & Coefficient & Standard Error & t-statistic & Probability \\
\hline Gold(First difference) & -1.185105 & 0.066025 & -17.94948 & 0.0000 \\
\hline C & 4.130586 & 3.958236 & 1.043542 & 0.2978 \\
\hline R- squared & 0.592050 & Mean dependent variable & 0.117946 \\
\hline Adjusted R-squared & 0.590212 & \multicolumn{2}{l|}{ S.D dependent variable } & 92.39581 \\
\hline Standard Error of regression & 59.14690 & Akaike Information criterion & 11.00681 \\
\hline Sum squared residual & 776634.9 & Schwarz criterion & 11.03727 \\
\hline Log Likelihood & -1230.763 & Hannan-Quinn criterion & 11.01911 \\
\hline F- statistic & 322.1837 & Durbin - Watson statistic & 2.028845 \\
\hline Probability (F- statistic) & 0.000000 & \multicolumn{2}{l|}{} \\
\hline
\end{tabular}

Note: Exogenous: Constant, Lag length: 0 (Automatic - based on Schwarz criterion, Max lag =11

The Table -6 indicates the results of ADF test for first difference of gold price between 2000-01 and 2017-18. The results of the test are analysed through $p$ values and $t$ statistic. The observed $p$ value is 0.0000 , which is less than $5 \%$. As per the guidelines the null hypothesis is rejected if the observed $p$ value is less than $5 \%$. Since the observed $p$ value ( 0.0000$)$ is less than $5 \%$, the null hypothesis is rejected. It indicates the time series data of the first difference of gold price for the period of observation is stationary.

The observed $t$ statistic value is -17.94 . As per the guidelines the null hypothesis is rejected if the absolute value of the observed $t$ statistic is more than the absolute critical value of $t$ statistic. Since the observed absolute $t$ statistic value is more than the absolute critical value (2.89) of t statistic at $5 \%$ significance level, the null hypothesis is rejected. Hence the analysis of ADF test indicates the first difference of the time series data of gold price for the period of observation is stationary.

Table 7: ADF Test for First difference of Gold Price for the Period between 2000-01 and 2017-18 (Trend and Intercept)

\begin{tabular}{|l|c|c|c|c|}
\hline \multicolumn{1}{|c|}{ Variable } & Coefficient & Standard Error & t-statistic & Probability \\
\hline D(S(-1) & -1.188724 & 0.066157 & -17.96813 & 0.0000 \\
\hline C & 10.63045 & 8.010649 & 1.327040 & 0.1859 \\
\hline Trend & -0.057160 & 0.061239 & -0.933387 & 0.3516 \\
\hline R- squared & 0.497196 & Mean dependent variable & -0.460108 \\
\hline Adjusted R-squared & 0.480248 & S.D dependent variable & 19.21673 \\
\hline Standard Error of regression & 13.85408 & Akaike Information criterion & 8.137095 \\
\hline Sum squared residual & 17082.26 & \multicolumn{2}{l|}{ Schwarz criterion } & 8.246024 \\
\hline Log Likelihood & -374.3749 & Hannan-Quinn criterion & 8.181077 \\
\hline F- statistic & 29.33581 & Durbin - Watson statistic & 1.816728 \\
\hline Probability (F- statistic) & 0.0000 & \multicolumn{3}{|l}{} \\
\hline
\end{tabular}

Note: Exogenous : Constant, Linear Trend, Lag length: 0 (Automatic - based on Schwarz criterion, Max lag =11)

The Table-7 indicates the results of ADF test of first difference (trend and intercept) of gold price between 200001 and 2017-18. The results of the test are analysed through $p$ values and $t$ statistic. The observed $p$ value is 0.0000 , which is less than $5 \%$. The test result is statistically significant at $5 \%$ confidence level. Hence the null hypothesis of non stationary is rejected. It indicates the time series data of the first difference of gold price for the period of observation is stationary. 
The observed $t$ statistic value is -17.96.02. As per the guidelines the null hypothesis is rejected if the absolute value of the observed $t$ statistic is more than the absolute critical value of $t$ statistic. Since the observed absolute $t$ statistic value is 8.02 which is more than the absolute critical value (3.45) of t statistic at $5 \%$ significance level, the null hypothesis is rejected. Hence the analysis of ADF test indicates the first difference of the time series data of gold price for the period of observation is stationary.

Table 8: ADF Test for First difference of Gold Price for the Period between 2000-01 and 2017-18 (No Trend and Intercept)

\begin{tabular}{|l|c|l|c|c|}
\hline \multicolumn{1}{|c|}{ Variable } & Coefficient & \multicolumn{1}{c|}{ Standard Error } & t-Statistic & Probability \\
\hline D(S(-1) & -1.181214 & 0.065932 & -17.91557 & 0.0000 \\
\hline R- squared & 0.590048 & Mean dependent variable & -0.429255 \\
\hline Adjusted R-squared & 0.590048 & S.D dependent variable & 19.11548 \\
\hline Standard Error of regression & 59.15870 & Akaike Information criterion & 8.16945 \\
\hline Sum squared residual & 780444.5 & Schwarz criterion & 8.19651 \\
\hline Log Likelihood & -1231.311 & Hannan-Quinn criterion & 8.18038 \\
\hline Durbin-Watson statistic & 2.026010 & & \\
\hline
\end{tabular}

Note: Exogenous: None, Lag length: 0 (Automatic - based on Schwarz criterion, Max lag =11)

The Table- 8 indicates the results of ADF test of first difference (no trend and intercept) of gold price between 2000-01 and 2017-18. The results of the test are analysed through $\mathrm{p}$ values and $\mathrm{t}$ statistic. The observed $\mathrm{p}$ value is 0.0000 , which is less than $5 \%$. As per the guidelines the null hypothesis is rejected if the observed p value is less than $5 \%$. Since the observed $\mathrm{p}$ value $(0.0000)$ is less than $5 \%$, the null hypothesis is rejected. It indicates the time series data of the first difference of gold price for the period of observation is stationary.

The observed t statistic value is -17.91 as per the guidelines the null hypothesis is rejected if the absolute value of the observed $t$ statistic is more than the absolute critical value of $t$ statistic. Since the observed absolute $t$ statistic value is 8.55 which is more than the absolute critical value (1.94) of t statistic at $5 \%$ significance level, the null hypothesis is rejected. Hence the analysis of ADF test indicates the first difference of the time series data of gold price for the period of observation is stationary. The application of $\mathrm{ADF}$ test for the first difference of gold price shows the variables are stationary for all the three tests i.e. only intercept, trend $\&$ intercept and no intercept. Therefore, the raw data of gold price is converted into first difference to make it stationary. Once the variable becomes stationary, it can be applied in any time series models such as VAR, VECM and Granger Causality test.

\section{ARMA (1,1) Model of Price Forecasting}

ARMA $(1,1)$ model is used to forecast the future price of Gold in the spot market for the period of 24 months from April 2013 to March 2015. The historical price of Gold in the spot market had been taken as the basis to forecast the future price. 


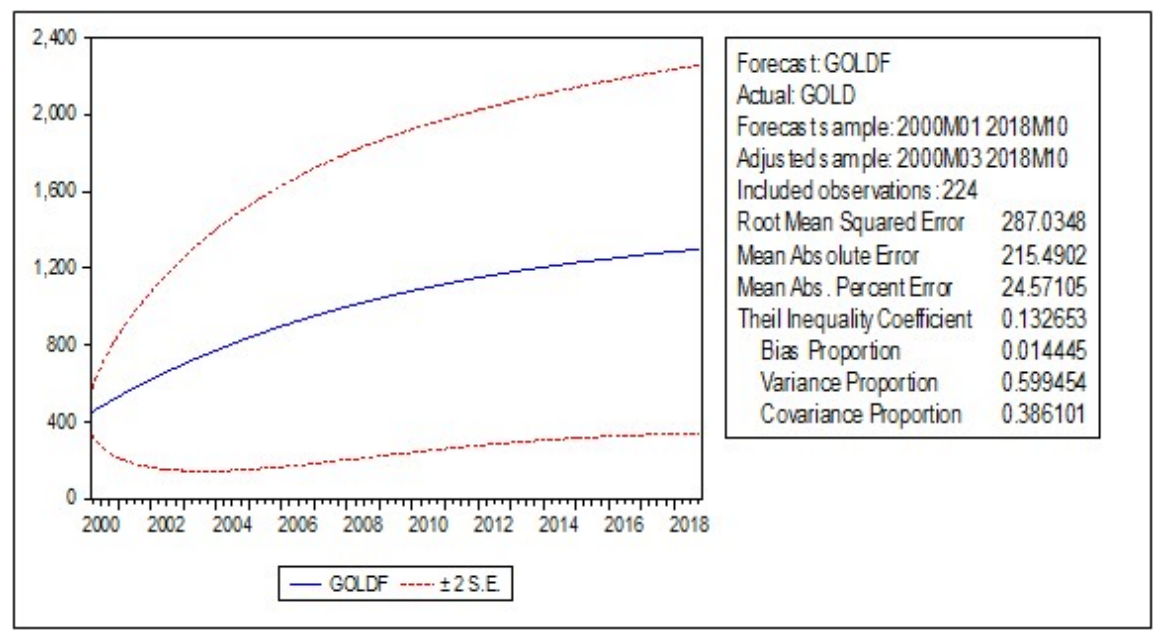

Figure 5: ARMA Model : Forecasting Gold Price Accuracy

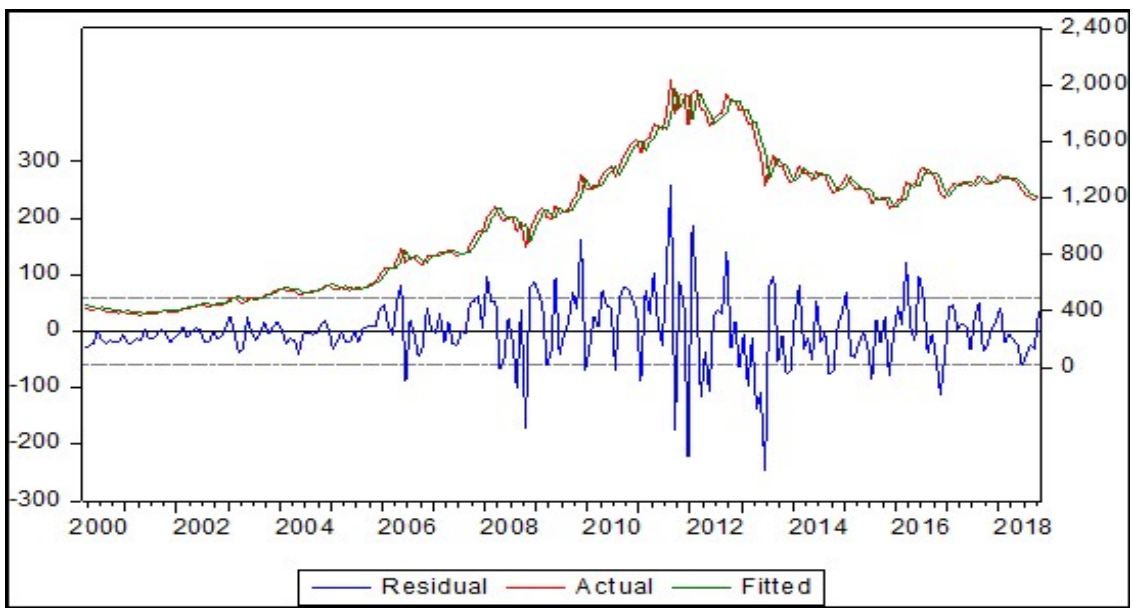

Figure 6: The ARMA Model of Gold Price Forecasting from 2000 to 2018.

The Figure - $5 \& 6$ shows the output of ARMA model of price forecasting. It is ascertained that the volatility of price movement of Gold in the spot market is likely to increase from the current level. The model projects the present scenario of higher volatility is expected to continue for the next 24 months.

\section{Normality Test for Monthly Returns of CNX Nifty}

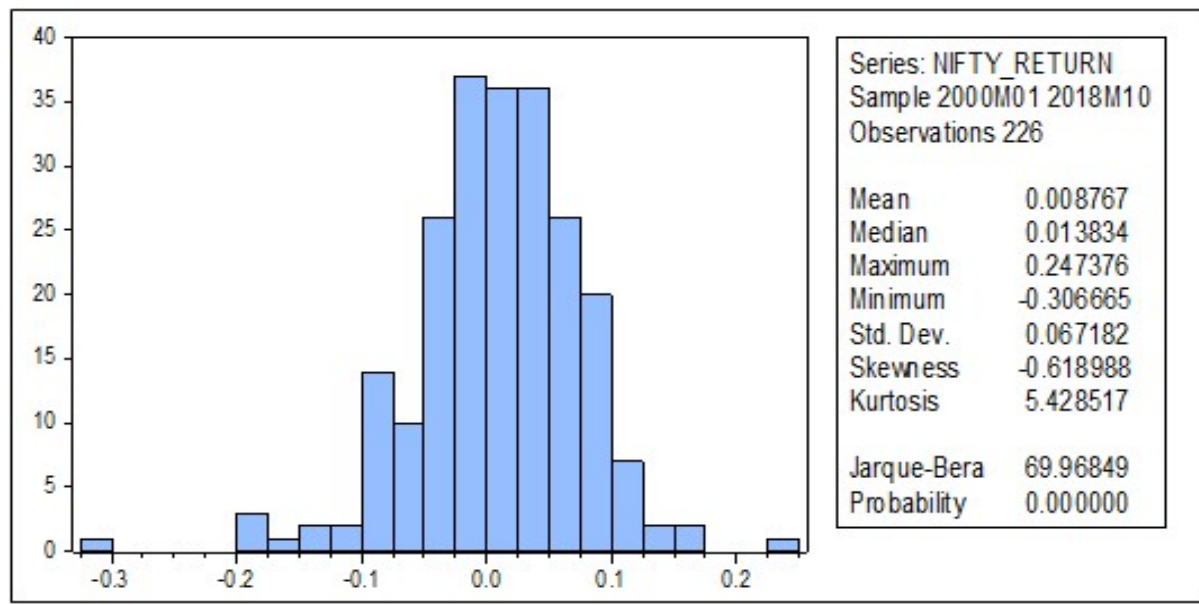

Figure 7: Descriptive Statistics of CNX Nifty (Monthly Return) for the Period from 2000 to 2018. 
The Figure - 7 shows the descriptive statistics of monthly returns of spot price of Nifty The above table shows Nifty returns for the period between 2000 and 2018. The nature of distribution of the series is analysed on the basis of Skewness, Kurtosis and Jarque - Bera test. The observed Skewness value is $(-0.61)$ is less than zero. It indicates the series is skewed towards left. The observed kurtosis value (5.42) is more than the critical value (3) which indicates the distribution is peaked and shows the formation of "Leptokurtic" kurtosis. Both the results indicate the series is not normally distributed. It shows the presence of many outliers or shocks in the series of monthly returns due to cyclical, seasonal variations and global demand and supply factors.

The obtained Jarque Bera statistic value is 69.96 and the probability is less than $5 \%$. It shows the test result is significant at $5 \%$ confidence level. Further Jarque - Bera statistic value (11.44) is more than the Chi -square test critical value (5.99) at 2 degrees of freedom at $5 \%$ significance. Therefore, the null hypothesis of normal distribution is rejected and alternate hypothesis of non-normal distribution is accepted. It shows the presence of wide dispersion of the monthly returns. It is ascertained from the test results that the monthly returns of Nifty in the spot market varied between $-30.6 \%$ and $24.73 \%$ for the period of observation with a standard deviation of $6.7 \%$.

\section{Analysis of Relationship between Gold and Stock Market}

Many investors hold gold and silver to hedge against various economic crises. But does this hedge hold up during stock market crashes? Knowing what effect a market plunge and subsequent dollar collapse will have on silver and gold is vital to making investment decisions now and then deciding what course to take should a major recession or depression occur.

While gold has an inverse relationship with the dollar, stocks markets also have a deep connection to the metal. Investors commonly perceive gold as a haven in the event of a severe stock market downturn. Presumably, when we experience a global market decline, stocks and currencies move downward. Some investments become less desirable and investors assume gold will give them some breathing room. However, this does not always hold true, and investors can get burnt.

Gold rose more than 2,300 percent from its low in 1970 to the 1980 peak. So it isn't terribly surprising that it fell with the broader stock market at that point. In recent years, the situation has been the exact opposite. Gold endured a 45 percent decline from its 2011 peak to its 2016 low, which was one of its worst bear markets in modern history. At the same time, this isn't entirely a shock either, given its quick gains during the 2008 crisis and the $2011 \mathrm{crash}$.

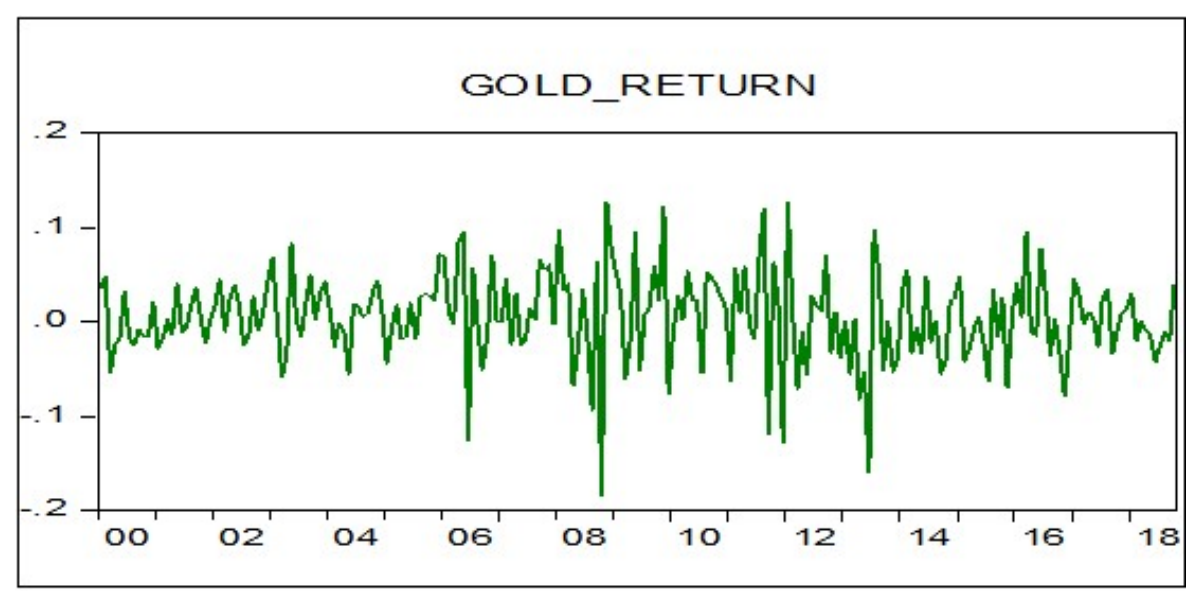




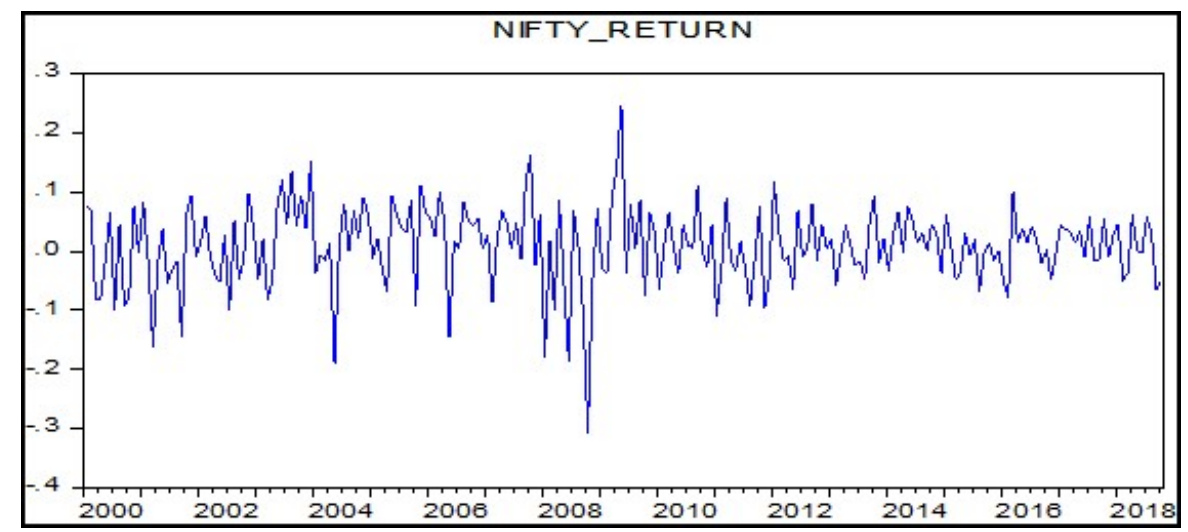

Figure 9: Trend in Return of Gold and Stock Market Index (CNX Nifty) during the Study Period.

\section{Granger Causality Test of Gold and Stock Market}

The Granger Causality test is a statistical hypothesis test for determining whether one-time series is useful in forecasting another series. This was proposed by Granger (1969) and popularized by Sims (1972)

Steps involved in Granger Causality Test,

- Step 1: Regress the first orders of the series of one variable with the other for the period of observation. Assume a particular autoregressive lag length $\mathrm{p}$, and estimate the unrestricted equation by ordinary least squares (OLS)

- $\quad$ Step 2: Selection of Optimal lag

The outcome of the Granger test is sensitive to the number of lags introduced in the model. Optimal lag is selected by running trial and error for various lags under Vector Error Correction (VEC) and Vector Auto Regressive (VAR) models. The time series is said to endogenous under VEC and exogenous as per VAR. Both the assumptions were tested under the trial and error method. The optimal lag is selected by observing the minimum Akaike Information Criterion (AIC) calculated from the trail and errors of VEC and VAR models.

Table 9: Pairwise Granger Causality Test of GOLD Price and CNX Nifty during the Study Period from 2000 to 2018

\begin{tabular}{|c|c|c|c|c|}
\hline \multicolumn{3}{|c|}{ Pairwise Granger Causality Tests } \\
\hline Sample: 2000M01 2018M10 \\
\hline Lags: 2 & Obs & F-Statistic & Prob. & Results (Ho) \\
\hline Null Hypothesis: & 224 & 0.45565 & 0.6346 & Accepted \\
\hline GOLD_RETURN does not Granger Cause NIFTY_RETURN & 224 & 0.95851 & 0.3851 & Accepted \\
\hline NIFTY_RETURN does not Granger Cause GOLD_RETURN &
\end{tabular}

The direction of causation between Gold and NIFTY is tested by applying Engle Granger Causality test and the results are tabulated in the Table - 9. The pair wise relationship among the three variables is examined for the period between 2000 and 2018. The Granger causality test is applied to examine the nature of association of money supply and inflation indices. The test is to examine the association of three variables.

The causality of gold with market index is tested in a bivariate framework. The hypotheses are tested for both unidirectional and bidirectional causality. The significance of the result is examined using F Test. The causal relationship is tested pairwise between gold and nifty. The application of Granger causality test shows there is no causal relationship among gold and stock market in India. 


\section{DISCUSSION AND CONCLUSIONS}

The study is based on the secondary data i.e., the historical price of Gold and Nifty index. The data analysis was done under two major categories. First being the statistical analysis and the second one is the application of econometric tools to test the hypothesis. The econometric tools used in the study are forecasting and Granger causality. India is one of the largest markets for gold, and growing affluence is driving growth in demand. The factors influencing gold price are inflation, changes in global price, Central bank gold reserves, fluctuating rates of interest, jewellery demand, investment demand and central bank demand. The quartile - quartile analysis of gold shows the minimum price of gold for the observation period is $\$ 371$ per ounce and the maximum price is $\$ 2033.05$. The mean and median values are 1,030.90 and $1,354.53$ respectively. The first quartile price of the observation period is $\$ 548.94$ and the third quartile value is $\$ 1,354.53$ per ounce. The interquartile range is 982.83 . The descriptive statistics of monthly average spot price of Nifty for the period ranging from 2008 to 2018. The nature of distribution of the series is examined by applying Skewness, Kurtosis and JarqueBera test of normality. For a series to be normally distributed the Skewness value should be equal to zero and the Kurtosis should be equal to 3 . The observed Skewness value (0.39) is not equal to zero and it is positive. It indicates the variables are skewed towards right. The observed kurtosis value (2.14) is less than the critical value (3) which indicates the tail is flat and shows the formation of "Platykurtic" kurtosis. Both the values of Skewness and Kurtosis indicate nonnormal distribution of series of spot price of Nifty for the period of observation. The Granger Causality test is a statistical hypothesis test for determining whether one time series is useful in forecasting another series. The test results are statistically significant at $5 \%$ confidence level. Therefore, it is inferred that there is no causality among the two variables (Gold and CNX Nifty).

\section{CONCLUSIONS}

During the period of global financial crisis, stock markets crashed but gold price continues to increase in the country. This could be explained as follows. The extent of holding of gold by Central banks are wide spread but stocks are not held by all, though retail participation in the Stock Markets might have gone up in the last few years. People consider gold the safe haven investment as a financial asset and as jewellery. Traditionally, gold has been more attractive than bank deposits, stocks and bonds. In developing countries, individual investors have often trusted gold as a better investment. In many countries, gold remains as the basic form of savings, but recently many innovative financial products have been lunched relating to gold. Recently derivatives such as gold forwards, futures and options have become very popular and have been traded on various exchanges around the world and over-the-counter directly in the private market. This is the fact that some variables like gold price can influence financial markets deeply, attracts attention in both academic and practical researches. This matter is spotlight especially in the period of crisis time. In one hand stock exchange is an appropriate organized market for investment and in the other hand traditionally gold has found its principal use as a store of value and make a safe heaven. A safe haven can be broadly defined as an asset that protects investors' wealth against financial crisis. Therefore, an asset with a stable real value or, at least a stable nominal value, is an uncontroversial safe haven, as it allows its holder to resell it without loss at any time especially in financial markets collapse. Also the stock index that shows market behaviour is highly sensitive to expectations while the price of gold usually has an important role in forming of expectations as well as many subjective and unpredictable and non-quantifiable factors in relatively short terms. The price of gold rises, the value of dollar rises against the Rupee. This puts strain on the economy as inflation increases with energy costs. Because of high inflation people invest more in gold and less in stocks causing the stock markets to fall. This 
research examines the relationship between gold and stock market. It is found that there is a relationship between gold and stock market.

\section{SCOPE FOR FURTHER RESEARCH}

The researcher has focused his study on exploring the relationship between gold and stock market. The scope of the research is confined to Indian market. However, the two futures constitute significant volume in the commodities futures exchange. While studying the relationship among the three variables, further research can be done by widening the scope to include global markets. The researcher has used econometric tools in forecasting and Granger Causality. Further research in this domain can be carried out with machine learning algorithms. It provides opportunity to explore various models and forecasting and select the best model that provides high level of forecasting accuracy. Use of machine learning algorithms may reduce the time and also facilitates the researcher to deal with large volume of data. The researcher has used monthly data in this study. Further research can be done with high frequency data and using machine learning models as tool to draw inference.

\section{REFERENCES}

1. Aktham M (2003). Causal Relations among Stock Prices and Macroeconomic Variables in the Small. Open Economy of Jordan. Economics \& Administration, 17 (2), 3-12. https://dx.doi.org/10.2139/ssrn.317539

2. Andy C. C. Kwan, John A. Cotsomitis and Benjamin Kwok (1996). Exports, Economic Growth and Exogeneity: Taiwan 195388. Applied Economics, 28, 467-471. https://doi.org/10.1080/000368496328597

3. Claire G. Gilmore, Ginette M. McManus, Rajneesh Sharma and Ahmet Tezel (2009). The Dynamics of Gold Prices, Gold Mining Stock prices and Stock Market Prices Comovements. Research in Applied Economics, 1 (1), 1-19.

4. Cuong Nguyen, M. Ishaq Bhatti, Magda Komorniková and Jozef Komornik (2016). Gold Price and Stock Markets Nexus under Mixed-Copulas. Economic Modelling, 58, 283-292. http://dx.doi.org/10.1016/j.econmod.2016.05.024

5. Dennis Bams, Gildas Blanchard, Iman Honarvar and Thorsten Lehnert (2017). Does oil and gold price uncertainty matter for the stock market? Journal of Empirical Finance, 44, 2017, 270-285. https://doi.org/10.1016/j.jempfin.2017.07.003

6. Hina Shahzadi, \& Muhammad Naveed Chohan. (2011). Impact of Gold Prices on Stock Exchange: A Case Study of Pakistan. http://saicon2011.ciitlahore.edu.pk/Economics/1038.pdf

7. Işıl Akgül, Melike Bildirici and Selin Özdemir (2015). Evaluating the Nonlinear Linkage between Gold Prices and Stock Market Index Using Markov-Switching Bayesian VAR Models. Procedia - Social and Behavioral Sciences, 210,408 - 415. https://doi.org/10.1016/j.sbspro.2015.11.388

8. Kasilingam Lingaraja, Selvam Murugesan, Vasanth Vinayagamoorthi and Gayathri Mahalingam (2014). Co-Movements and Inter-Linkages of Indian Stock Market with Emerging Stock Market Indices in Asia. International Journal of Applied Business and Economic Research, 12 (4), 1045-1064.

9. Kasilingam Lingaraja, Veluchamy Ramanujam, Lakshmanan Eswaran, Thangaraj Viswanathan and Chellaswamy Dhayanand (2020). Impact of Demonetization on Stock Price Volatility of Public Sector Banks in India: Special reference to BSE. International Journal of Management, 11(3), 408-418. https://doi.org/10.34218/IJM.11.3.2020.043

10. Kathiravan Chinnadurai, Selvam Murugesan, Sankaran Venkateswar, Lingaraja Kasilingam, Sigo Marxia Oli (2017). Effect of Temperature on Stock Market Indices: A Study on BSE and NSE in India. International Journal of Economic Research, 14 (15-Part 3), 171-181. 
11. Kathiravan Chinnadurai, Selvam Murugesan, Venkateswar Sankaran, Lingaraja Kasilingam, Amirdha Vasani Sankarkumar and Kannaiah Desti (2018). An Empirical Investigation of the Inter-Linkages of Stock Returns and the Weather at the Indian Stock Exchange. Academy of Strategic Management Journal, 17 (1), 1-14.

12. Kwon CS and Shin TS (1999). Cointegration and Causality between Macroeconomic Variables and Stock Markets Returns. Global Finance Journal, 10, 71-81. https://doi.org/10.1016/S1044-0283(99)00006-X

13. Lingaraja Kasilinga, Jothi Baskara Mohan, C, Selvam Murugesan, Raja Mariappan and Kathiravan Chinnadurai (2020). Exchange Rate Volatility and Causality Effect of Sri Lanka (LKR) with Asian Emerging Countries Currency against USD. International Journal of Management (IJM), 11 (2), 191-208. https://doi.org/10.34218/IJM.11.2.2020.021

14. Lingaraja Kasilingam, Selvam Murugesan and Vasanth Vinayagamoorthi (2014). Co Movements and Inter-Linkages among Emerging and Developed Stock Markets in Asia with Reference to Singapore Stock Exchange. International Research Journal of Finance and Economics (IRJFE), 122 (), 102-120.

15. Lingaraja Kasilingam, Selvam Murugesan and Vasanth Vinayagamoorthi (2015). Long Run Dynamic Linkages between Emerging Stock Markets in Asia and a Developed Stock Market (DJIA). Research Journal of Applied Sciences, 10 (5), $203-$ 211.

16. Lingaraja Kasilingam, Selvam Murugesan, Vasanth Vinayagamoorthi and Ramkumar, Ramachandran Rajesh (2015). LongRun Overseas Portfolio Diversification Benefits and Opportunities of Asian Emerging Stock Markets and Developed Markets. International Journal of Economics and Financial Issues, 5 (2), 324-333.

17. Lingaraja, Kasilingam, Selvam Murugesan and Vasanth Vinayagamoorthi (2014). The Stock Market Efficiency of Emerging Markets: Evidence from Asian Region. Asian Social Science, 10 (19), 158-168. https://doi.org/10.5539/ass.v10n19p158

18. Lingaraja, Kasilingam, Selvam Murugesan, Ramanujam Veluchamy, Marxia Oli Sigo and Chinadurai Kathiravan (2020). Stock Market Movements and Linkages between Emerging Markets in Asia and Developed Market Indices: Short Run and Long Run Analysis. Journal of Critical Reviews, 7 (7), 619-629. https://doi.org/10.31838/jcr.07.07.111

19. Muhammad Akbar, Farhan Iqbal and Farzana Noor (2019). Bayesian Analysis of Dynamic Linkages among Gold Price, Stock Prices, Exchange Rate and Interest Rate in Pakistan. Resources Policy, 62, 154-164. https://doi.org/10.1016/j.resourpol.2019.03.003

20. Mu-Lan, Ching-Ping and Tzu-Ying (2010). Relationship among Oil Price, Gold Price, Exchange Rate and International Stock Markets. International Research Journal of Finance and Economics, 47, 1450-2887

21. Nafeesa Yunus (2020). Time-Varying Linkages among Gold, Stocks, Bonds and Real Estate. The Quarterly Review of Economics and Finance, Available online 27 February 2020. https://doi.org/10.1016/j.qref.2020.01.015

22. Osamah M.Alkhazali and Taisier A.Zoub (2020). Gold and Portfolio Diversification: A Stochastic Dominance Analysis of the Dow Jones Islamic Indices. Pacific-Basin Finance Journal, 60, 101264. https://doi.org/10.1016/j.pacfin.2020.101264

23. Ramanujam, V and Bhuvaneswari (2015). A Growth and Performance of Indian Mutual Fund Industry during Past Decades. International Journal of Advance Research in Computer Science and Management Studies, 3(2), 283-290.

24. Ramanujam, V and Leela, L (2014). The Effect of Macro-Economic Variables on Stock Prices in Emerging Stock Market: Empirical Evidence from India. Indian Journal of Applied Research, 4 (6), 1-8

25. Ray, S. (2012). Testing Granger Causal Relationship between Macroeconomic Variables and Stock Price Behaviour: Evidence from India. Advances in Applied Economics and Finance, 3(1), 470-481. 
26. Sadorsky P (1999). Oil Price Shock and Stock Market Activity. Energy Economics, 21 (5), $449-469$. https://doi.org/10.1016/S0140-9883(99)00020-1

27. Sadri H and TayebiSani E (2012). The Impact of Crude Oil, Gold Price and Their Volatilities on Stock Markets: Evidence from Selected Member of OPEC. Journal of Basic and Applied Scientific Research, 2, 10472-10479.

28. Safi R and Soytas U (2006). The Relationship between Stock Returns, Crude Oil Prices, Interest Rates, and Output: Evidence from a Developing Economy. The Empirical Economics Letters, 5 (4), 205 - 220.

29. Shubhasis Dey and Aravind Sampath (2018). Dynamic Linkages between Gold and Equity Prices: Evidence from Indian Financial Services and Information Technology Companies, Finance Research Letters, 25, 41-46. https://doi.org/10.1016/j.frl.2017.10.002

30. Smith G (2001). The Price of Gold and Stock Price Indices for the United States. Adrienne Roberts FT Personal Finance.

31. Sulaiman, D., S. Naqvi, I. Lal, \& S. Zehra. (2012). Arbitrage Price Theory (APT) and Karachi Stock Exchange (KSE). Asian Social Science, 8(2), 253-258. http://dx.doi.org/10.5539/ass.v8n2p253

32. Chandrabai, DRT, and DRK Suresh. "Assessment of Machine Learning Techniques for Gold Price Predictions." (1991). International Journal of Mechanical and Production Engineering Research and Development (IJMPERD) 10.3 (2020):58795886

33. Buche, Anish. "Factors Affecting Volatility in Indian Stock Markets." International Journal of Financial Management (IJFM) $5.3(2016): 1-8$

34. Barik, Saktikanta, and Saroj Kanta Biswal. "Interdependency Study of Stock Index of India with Reference to Nifty and Indian Currency Exchange Rate." International Journal of Accounting and Financial Management Research (IJAFMR) 9.2 (2019):21-28

35. Chennappa, D., and V. Ravi. "Performance Evaluation of Large Cap Funds." International Journal of Business Management \& Research (IJBMR) 9.2 (2019):13-26

36. Sharma, Arun Kumar. "Relationship Between the Selected Sectoral Indices and Nifty." International Journal of Business and General Management (IJBGM) 3.3 (2014): 117-124.

37. Omar, Arti. "Var Analysis on FII's Portfolio Decisions-Cause Effect Analysis in Indian Context." (1990). International Journal of Financial Management (IJFM) 5.2 (2016):1-16 